\title{
Non-Verbal Tools of Intercultural Communication in the Practice of Teaching Russian as a Foreign Language
}

\section{Soboleva Anna', Urvantceva Natalia²}

${ }^{1}$ Petrozavodsk State University, Petrozavodsk, Republic of Karelia, Russia

2 Petrozavodsk State University, Petrozavodsk, Republic of Karelia, Russia Corresponding author: Soboleva Anna, aviarieva@gmail.com

Abstract. The work is devoted to the analysis of tools of non-verbal communication in the context of intercultural communication during lessons of Russian as a foreign language. The scientific novelty of the research is determined by a comprehensive analysis of the features of non-verbal tools of communication in the lessons of the Russian language with foreign students from a methodological point of view, and also by a sign dictionary of non-verbal communication tools, which can be used by teachers of Russian as a foreign language for preparing classes in a multicultural environment. Not only has the comprehensive analysis revealed the peculiarities of perception of some tools of non-verbal communication depending on the cultural identification of the recipient, but it has also helped to distinguish successful communication strategies and tactics for lessons of Russian as a foreign language. The right choice of a teacher's non-verbal communication tools in the pedagogical process helps to increase the effectiveness of learning Russian as a foreign language and to maintain a favorable atmosphere in the classroom in the context of intercultural interaction.

Keywords: intercultural communication, language teaching, non-verbal tools, Russian as a foreign language (RFL)

\section{Introduction}

One of the components of optimal pedagogical communication is the teacher's perfect command of the tools of influence - the technique of pedagogy, verbal and non-verbal tools of communication. A large number of studies in linguistics, anthropology, paralinguistics, philosophy, pedagogy, psychology, and semiotics are devoted to the issue of non-verbal communication. At the same time, as the scientific research analysis shows, the concept 
of non-verbal tools of foreign language communication is not included in modern programs on Russian as a foreign language (hereinafter - RFL). In addition, this aspect has not been covered in manuals and teachers' books about methods of teaching RFL. Nowadays the issue of non-verbal tools of communication in the context of intercultural communication has not been barely studied.

There is a small number of studies devoted to the analysis of peculiarities of non-verbal communication in an intercultural environment at the lessons for speakers of other languages [Eremeeva, 2015], [Talybina, Polyakova, Minakova, 2015], [Nizamutdinova, 2016], [Volskaya, 2017] [Xiang Guangyun, 2017], [Bejenari, Pomortseva, 2018], [Velikanova, 2019]. In this regard, there is "a contradiction between, on the one hand, the existing practical need to master skills of non-verbal communication for receptive purposes, as well as the willingness to use them in situations of real intercultural contacts, and, on the other hand, their absence in the content of modern curricula and thus specialists' unawareness of how to implement them during lessons [Talybina, Polyakova, Minakova, 2015, 17].

\section{Resources and research methods}

The aim of the research is to analyze the tools of non-verbal communication in the context of intercultural communication in a RFL lesson. A set of research methods was used: observation method, analysis of the scientific database on the research topic, comparative, descriptive, statistical and comparative methods. The object of the research are the various non-verbal tools which are relevant for intercultural communication; the subject of the research is the analysis of non-verbal tools of communication in the lessons of Russian as a foreign language when there is no intermediate language for communication.

The practical value of the research is based on the fact that its results can be used during preparation for teaching RFL in a multicultural environment. The working hypothesis of the research is based on the assumption that the right choice of the teacher's non-verbal communication tools helps to increase the effectiveness of learning Russian as a foreign language. 


\section{Results and reflections}

3.1. Theoretical objectives of the use of non-verbal communication tools in a RFL lesson

\subsubsection{The influence of globalization on changes in the use}

of non-verbal communication tools

The increasing competitiveness and accessibility of Russian education in the world market of educational services contributes to the influx of foreign students. The number of citizens of other countries enrolled in programs of higher education in state and municipal institutions on a general admission basis in the academic year 2000/2001 was 59,000, in the academic year 2005/2006 it was 78,100, in the academic year 2017/2018 228,900, and in the academic year 2018/2019247,700 [Rossiya v tsifrakh, 2019, 143]. According to predictions, by the year 2025, 710,000 foreigners will study full-time at Russian universities and institutions of secondary vocational education. The contemporary internationalization of the Russian educational process, "which occurs due to foreign students' enrollment into higher professional educational institutions, creates a need for willingness to perform intercultural communication based on respect, human dignity, and open-mindness to deal with other cultures" [Evtyugina, 2018, 454]. In this regard, the current task is to define the integration level of foreign students in an educational environment of another language [Urvantseva, 2019, 59].

During the period of intercultural adaptation to a foreign country, foreigners experience a linguistic and cultural shock. Foreign students' acquaintance with a new culture is connected with physical, psychological and emotional discomfort. In the new educational environment, foreigners face an unfamiliar sign system. Foreigners often perceive the other culture through the prism of their own, which contributes to the emergence of misunderstanding, an increase in the number of intercultural problems and conflicts, the solution of which requires knowledge of the patterns of intercultural communication [Boldyrev, 2010,4]. An RFL teacher's awareness of acquired or nationally specific behavior which reflects "the formation of personal behavior, the use of certain non-verbal components" [Vasilieva], helps to understand better foreign students.

When working with foreign students the impact of globalization on changes in the use of non-verbal communication should be taken into account. The process of globalization contributes to convergence of people, their cultural peculiarities, and this, in turn, leads to "reinforcing of their 
interaction, interdependence, the expansion of cultural borrowing, the elaboration of certain cultural universals of global significance" [Nabok, 2010, 206]. Despite the fact that in different countries people prefer different social networks, a thumb up (like) is interpreted in all cultures in the same way - it is a sign of approval and consent. This happened due to the active spread of the social network "Facebook" in the world. When communicating with foreigners, some observations were made. For example, a sign that in most countries means "everything is okay" (the thumb and forefinger are in the shape of a ring, and other fingers tend upward) but was considered an insult in Turkey, has now lost its meaning and no longer carries a negative connotation.

\subsubsection{Linguodidactic potential of the use}

of non-verbal communication tools at a RFL lesson

The field of non-verbal communication consists of all body signals with a communication value sent by a person or created by the environment. The relevance of their use is confirmed by the fact that "the transmission of information only through words is valid only for $7 \%$, through the tone of voice and intonation of speech - for $38 \%$, with the help of non-verbal tools - gestures, facial expressions, body language - for $55 \%$ " [Mehrabian, 2009, 3]. A command of a foreign language is impossible without knowledge of the non-verbal code, therefore the issue of awareness of non-verbal tools of intercultural communication is very relevant.

Foreign students at the initial stage of their education do not speak Russian. In a RFL lesson, the use of non-verbal communication tools may often be the only possible way of communication. At this level of formation of foreign language intercultural competence, students should have intercultural skills ("to recognize and perceive culturally specific information, to compare the facts of foreign and native cultures, to find differences and similarities between them, to plan and perform their verbal and non-verbal behavior taking into account intercultural differences" [Sergeeva and Pokhodzey, 2014, 79]) and intercultural capabilities ("to predict the perception and behavior of native speakers of the language and culture, correct behavior in verbal and non-verbal communication in various spheres of communication: professional, personal, educational, social".

The success of intercultural communication in teaching Russian as a foreign language is largely determined by the teacher's ability to create a trusting contact with foreign students. And such a contact depends not only on 
what a teacher says, but also on his or her non-verbal behavior. According to the hypothesis of socialization, the ability to reproduce non-verbal signals is mastered in practice with taking into account the example of others. The ability to recognize non-verbal signals is learned reactively: the sensitivity to their recognition is a necessary adaptation for an individual to be able to survive in a non-expressive environment [Butovskaya, 2004, 110].

Mastering the language of non-verbal communication is important not only for communication, but also for the formation of a second linguistic personality, that is a personality attached to the culture of the people whose language is being studied. It is necessary to understand the relationship between verbal and non-verbal units. A command of a language includes both an understanding of the national culture, and the willingness to understand the communicative behavior of the people of the country of the target language, here we are talking about intercultural competence. This is important not only for communication, but also for the formation of a linguistic personality in the multiethnic educational environment of the university.

3.2. Non-verbal communication in the pedagogical process with a multicultural audience

3.2.1. Determination of strategic approaches to organizing a RFL lesson taking into account the use of non-verbal communication tools

A RFL teacher needs to take into account a number of non-verbal behavior-related factors that can affect the organization of a lesson, the atmosphere, and also make the learning process more effective. It is necessary to monitor the vocal characteristics of your speech. The voice should be calm and moderately loud. At first it will be useful for students if the teacher exaggerates intonation constructions. The teacher should remember that a low voice is perceived better than a high voice.

For students who do not speak Russian or speak at a minimum level, it is necessary to see the teacher, pay attention to his gestures and facial expressions, this will help to build the educational process more effectively. The teacher is advised to move around the classroom, be at the same time always in sight of all students, not to sit in the classroom. The main requirement is to be able to maintain an eye contact with everyone in the classroom and stay in the sight of students.

Do not forget about the cultural characteristics of oculesics. Eye contact is an important part of dialogue and effective communication. Students from Arab countries will constantly maintain an eye contact with the teacher, their 
gaze can be described as direct and long, such a gaze can be confusing. Students from southern and central Africa will look down when they feel guilty.

Touches (haptic) play an important role in human communication and may be interpreted differently in different cultures. In Arab countries, a touch between men and women who are not related by marriage or kinship is unacceptable, so the touch of a female teacher to a male student may seem like a demonstration of tenderness and sympathy. South Asian countries will find it offensive if one touches a head.

The teacher should remember about proxemics. The distance between a teacher and a student depends on the type of communication. If we are talking about a situation where a teacher is giving a lecture to students, then it is defined as a public area. If a teacher delivers a language lesson for a small group, then it is a business communication zone that is $1.2-3.5$ meters. The comfortable communication distance can be perceived differently depending on the type of culture. The social zone of a student from the People's Republic of China will be significantly smaller compared to the one of a Russian student, therefore, it's highly likely that a Chinese student will violate a teacher's personal zone while communicating.

A RFL teacher should be prepared for the fact that students from Arab countries may involuntarily violate the boundaries of the teacher, and not perceive this negatively. On the one hand, the teacher must be ready for such behavior, and on the other hand, he or she should remember how his or her non-verbal behavior can affect students. Reducing the distance between a teacher and a student may be perceived by the latter as a threat [Dubina, 2012, 118].

Not only has the work with students at the preparation faculty of the university the aim of teaching them a needed language, but also of making them understand the rules of behavior in a new culture, the correct distribution of time (chronology). One of the teacher's tasks is to explain to foreign students that long delays are not allowed in Russia. Foreigners should change their habits formed under the influence of their native cultures.

Teachers must not use gestures that could be interpreted as offensive or derogatory. When working with students from China, you need to pay attention to how they count. It is important to understand that cases are often studied with their corresponding numbers. If a teacher shows a prepositional case (sixth case) to a student from China using fingers of both hands, there will be a misunderstanding. 


\subsubsection{A set of exercises for teaching non-verbal communication tools}

Teaching tools of non-verbal communication is only possible when the students have already had a command of Russian at least at A1 level. Certain tasks can be implemented at the A1 level, but a comprehensive study of non-verbal communication tools at the level of a beginner is not possible. Mastering a foreign language includes both studying vocabulary and grammar, and also understanding the culture of the target language. A teacher of Russian as a foreign language is a translator of Russian culture for students of other languages. Students make certain conclusions about Russian non-verbal behavior based on the behavior of the teacher, but this knowledge is not enough for a complete understanding of the non-verbal culture of Russians, therefore one of the teacher's tasks is to teach students to adequately perceive and understand the meanings of non-verbal behaviour. Here are some examples of exercises to practice grammar, vocabulary and phonetics and to understand the peculiarities of non-verbal communication.

1. Exercises to practice grammar, vocabulary and phonetics

1) The teacher can use non-verbal communication tools to work with grammar. For example, you can use your fingers to indicate the case number, therefore to explain a mistake or to help to make up a sentence. The student says the sentence: "I am from.... The teacher shows two fingers, which means that the student needs to use the second case. Students who do not have any particular difficulties do not always need help, but weaker students can be supported by tools of non-verbal communication.

2) Language rhythm

Tapping off the rhythm or clapping hands helps foreign students to develop the correct intonation, to identify the features of the intonation pattern. This method is great for people who receive basic information through hearing, as well as for kinesthetic learners, if students clap their hands or tap out a rhythm together with the teacher.

3) The game "Crocodile"

The first version of the game. Students write words on small identical pieces of paper, which are all folded into one bag. One of the group takes out a piece of paper and explains the meaning of the word using body language, without using the verbal expression of the words. It is necessary to explain as many words as possible in a limited amount of time. The one who explains the largest amount of words wins. The teacher can prepare the vocabulary in advance. 
The second version of the game involves playing in groups. Students are divided into several groups of 3-4 people. All students write words on pieces of paper, put them in one bag, which is passed from team to team. One of the group representatives takes out a piece of paper, explains as many words as possible, but only members of his team can guess. The team that is able to explain and guess the largest amount of words wins.

2. Exercises for understanding peculiarities of non-verbal communication

1) Exercise "Read the text"

In this exercise, variations in performance are acceptable, but the essence remains the same. It is necessary to read the same text with different moods. One of the main features of this exercise is that the emotional factor of perception is involved, which contributes to better grasping the information. Texts for reading are selected depending on the level of language proficiency. If you need to practice the pronunciation of certain sounds, you can use tongue twisters. The mood or given situations must also be selected based on the level of language proficiency. To make the task easier for students with a level of beginners, you can display the task on a slide with a picture that illustrates the situation/ mood.

Tasks for students with an elementary level.

Imagine that: you really want to sleep; you are sad; you are joyful; you are in a hurry; you're too hot.

Tasks for students who already speak the language at a basic level.

Imagine that you: worry before an exam; were in a hurry, but eventually missed the train; have met an old friend on the street, but you cannot talk to him because you are late, but you are trying to be polite; do not trust the information you read; don't believe you have won.

After completing the exercise, it is necessary to analyze the significance of the paralinguistic factors.

2) Exercise "What is he?"

Look at the picture of a person, choose a suitable adjective.

List of adjectives: calm, suspicious, joyful, surprised, scared, angry, sad, tired.

After completing the task, you can ask why the students have made such a choice, what details they have paid attention to. After the discussion, it is necessary to ask the student to show one of these emotions, the rest of the students must guess and name an adjective which is demonstrated.

3) Exercise "Empathic Broken Phone" 
Participants stand in a row one after another, so that participants can't see each others' faces during the game. The teacher tells an emotion to the last person in the row. He or she should transfer it to the next participant in the row. He or she taps the next participant on the shoulder, when he or she turns around, the first participant shows the emotion that was given to him without naming it. The second participant taps the next one on the shoulder and shows the emotion to him or her. One by one the emotion is finally shown to the first person in the row. He or she names it out loud. Everyone compares their results, analyzes whether everyone understood this movement. The first participant stands at the end of the line and makes up the next emotion himself and passes it on.

\subsection{Research of the ways to use non-verbal tools of communication} in pedagogical activity in the context of intercultural communication

3.3.1. Analysis of manuals and teachers' books on RFL

To determine the frequency of certain tasks in the educational literature, popular manuals on Russian as a foreign language of elementary level were analyzed. In the textbook of V.E. Antonova, M. M. Nakhabina, M. V. Safronova and A. A. Tolstoy "Doroga v Rossiyu [Road to Russia], tasks are designed using imperatives. It was the only one source where there were such tasks: "Draw this", "Draw pictures", "Find the same things/ captions" or "Remember".

In the textbook written by S. I. Chernyshov "Poyekhali! [Let's go!]” tasks are often presented only as a sample, students must understand what exactly needs to be done and complete the task according to the scheme; there was a task "Make a guess", which was not found in any other book.

M. N. Anikina's book called "Lestnitsa [Ladder]" is a part of the educational complex on Russian as a foreign language, which includes 21 levels, each of them offers exercises to master speech, language and interaction. The tasks are more sophisticated than in other analyzed textbooks. In the formulation of tasks, the notions "adjective", "noun" are used.

Tasks in the educational complex by T. L. Esmantova "Pyat' Elementov [Five Elements]" are presented in the form of nouns: "Dialogues", "Question - Answer", "Stress and Articulation."

In the book by Y.G. Ovsienko "Russkiy yazyk dlya nachinayushchikh [Russian for beginners]" all tasks are given in two languages - in Russian and in English. Tasks are presented using imperatives: "Make up the text" "Write", "Read", "Rewrite", etc. 
The textbook by L. V. Miller, L. V. Politova and I. Y. Rybakova "Zhyli-byli [Once upon a time]" is designed for intensive courses, but can also be used in the preparation faculties of Russian universities. Tasks are shaped in the form of imperatives: "Write", "Read", "Find in the dictionary", "Ask questions."

The classics among books on RFL is the textbook for preparation faculties written by M.M. Galeeva "Start" [Galeeva, 1986]. The exercises are presented in the form of imperatives: "Write", "Rewrite", "Listen", "Read".

When analyzing textbooks, types of tasks and their frequency were determined. It was found that the following tasks are most often used: "Answer questions", "Write", "Listen" - 5, "Watch" -6 and "Read" - 7. Less commonly used tasks such as "Make a picture / Draw", "Sign the pictures", "Show", "Put a stress mark", "Imagine." A detailed table with the research results is presented in Appendix 1 (See Table 1).

3.3.2. Analysis of non-verbal behavior of teachers of RFL

at the preparation faculty of Petrozavodsk State University

To make this research study complete, the non-verbal behavior of five teachers of Russian as a foreign at the preparation faculty of Petrozavodsk State University was analyzed by observing and analyzing video recordings of lessons with foreign students. As a result, it was found that the most frequent gestures are gestures that illustrate speech, complement it, thus reducing communicative difficulties. These gestures help the teacher to explain what to do next during the lesson. Gestures of regulation that control the stream of communication are also often used by teachers. A detailed table with the analysis results can be found in Appendix 2 (See Table 2).

Selected tools of non-verbal communication have had to meet two basic requirements: to be understandable to representatives of different cultures and not to be interpreted negatively in any other culture.

In total, 34 kinemes were selected, which we divided into 2 groups:

1. Teaching actions that monitor and regulate the work in classroom.

2. Actions to help explain grammatical categories.

When analyzing the use of non-verbal communication tools in a lesson of RFL, a gesture reference book was compiled, which describes universal non-verbal tools, which can be used in the classroom for the most effective teaching Russian as a foreign language. For its compilation, we have selected those tasks that are most often used by teachers of RFL in a lesson and are found in manuals. We limited ourselves to the elementary level because 
at this stage of language learning, the use of non-verbal communication tools is the most important in the educational process, since students do not have enough vocabulary to understand all teachers' verbal requests. In addition, sometimes the teacher and the student may not have an intermediary language, students may only know their native language.

The dictionary contains the name of the kineme, its description, application and illustrations. Names of the kinemes correspond to the vocabulary of the elementary level, since most of the selected non-verbal units are illustrative gestures that are used together with the verbal expression of an educational action. Kinemes can be changed by teachers, but the gestures should not repeat each other, meet the selection criteria described above, and be used systematically. The use of gestures described in the dictionary was tested at Petrozavodsk State University in the framework of teaching Russian to foreign students of the preparation faculty. It was determined that all gestures are understandable to the audience, do not cause unpleasant associations for anyone, and do not repeat somehow negative culturally determined gestures. The study has involved students from 23 countries (Africa, Asia, South America and Northern Europe). The dictionary is presented in Appendix 3 (See Table 3).

\section{Conclusions}

Not only did the comprehensive research study reveal the peculiarities of perception of some non-verbal communication tools depending on the cultural identification of the recipient, but it also highlighted successful communication strategies and tactics for lessons of Russian as a foreign language. Examples of the use of non-verbal communication tools were presented for teachers of RFL. A set of tasks for teaching non-verbal communication was developed, taking into account modern methods, teaching techniques and the principles of introducing new material.

As a result of observing the activities of teachers of RFL at Petrozavodsk State University, analyzing video records of RFL lessons and seven elementary-level textbooks, a sign dictionary for teachers of RFL was compiled, which reflects the results of a study on the ways of using non-verbal tools of communication in pedagogical activities in the context of intercultural communication. Gestures are divided into two groups: gestures that regulate work in a classroom and gestures that help to explain some grammar categories. The dictionary can be used by teachers of RFL in preparation for classes in a multicultural environment. The right choice of the teacher's non-verbal 
communication tools helps to increase the effectiveness of teaching Russian as a foreign language and maintain a favorable atmosphere at the lesson.

\section{Appendix}

Appendix 1.

Table 1

Tasks given in the manuals of RFL of the elementary level

\begin{tabular}{|c|c|c|c|c|c|c|c|c|c|}
\hline № & Task & 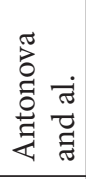 & 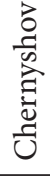 & 蔦 & 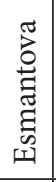 & $\frac{\tilde{z}}{\tilde{U}}$ & 状 & 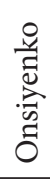 & $\begin{array}{l}\dot{\Xi} \\
\dot{\Xi} \\
\text { Zे }\end{array}$ \\
\hline 1 & Reconstruct the text & & & & & + & & + & 2 \\
\hline 2 & Say what is it/who is he/she & + & + & + & & & + & & 4 \\
\hline 3 & Make pictures / draw & + & & & & & & & 1 \\
\hline 4 & Add a needed form & & & + & & & & + & 2 \\
\hline 5 & Complete the dialogue & & & + & & & & & 1 \\
\hline 6 & Make a guess & & + & & & & & & 1 \\
\hline 7 & Ask a question / Ask & + & + & & & & + & & 3 \\
\hline 8 & Fulfill the table & & + & + & & & + & & 3 \\
\hline 9 & Remember & + & & & & & & & 1 \\
\hline 10 & Find the same things / captions & + & & & & & & & 1 \\
\hline 11 & Answer the questions & & + & + & + & & + & + & 5 \\
\hline 12 & Guess & & + & & & + & & & 2 \\
\hline 13 & Rewrite & & & & + & & & + & 2 \\
\hline 14 & Write & + & & + & + & + & & + & 5 \\
\hline 15 & Repeat & + & & & & + & + & & 3 \\
\hline 16 & Choose an adjective & & & + & & & & & 1 \\
\hline 17 & Sign the pictures & & & & & + & & & 1 \\
\hline 18 & Show & & & & & + & & & 1 \\
\hline 19 & Continuer / Fulfill a chain / sentence & + & & + & & + & & & 3 \\
\hline 20 & Open parenthesis & & & + & & & + & & 2 \\
\hline 21 & Listen & + & + & & + & + & + & & 5 \\
\hline
\end{tabular}


End of Table 1

\begin{tabular}{|c|c|c|c|c|c|c|c|c|c|}
\hline № & Task & 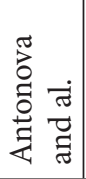 & 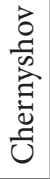 & 营 & 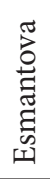 & 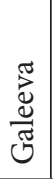 & 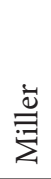 & 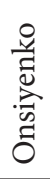 & 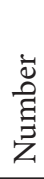 \\
\hline 22 & Look at the pictures & + & + & + & & + & + & + & 6 \\
\hline 23 & Connect & & + & + & + & & & & 3 \\
\hline 24 & $\begin{array}{l}\text { Make all possible variations of collo- } \\
\text { cations / dialogues / stories }\end{array}$ & + & + & & & & & & 2 \\
\hline 25 & Compare who or what? Yes or no? & + & + & + & + & & + & & 4 \\
\hline 26 & Put a stress mark & + & & & & & & & 1 \\
\hline 27 & Make a sentence & & + & + & & & & & 2 \\
\hline 28 & Imagine & & & + & & & & & 1 \\
\hline 29 & Read & + & + & + & + & + & + & + & 7 \\
\hline
\end{tabular}

Table 2

The use of non-verbal communication tools by the teachers of RFL in the lessons

\begin{tabular}{c|l|c|c|c|c|c}
\hline \multicolumn{2}{c|}{ Gesture } & 1 & 2 & 3 & 4 & 5 \\
\hline \multicolumn{7}{c}{ Actions of regulations } \\
\hline 1 & Together & + & + & + & & \\
\hline 2 & Attention! & & & + & + & \\
\hline 3 & Question & & + & & & \\
\hline 4 & Time (why are you late?) & + & & + & & \\
\hline 5 & You (plural) & & + & + & + & + \\
\hline 6 & Talk & + & & & & \\
\hline 7 & Yes/ you are right & + & + & & & + \\
\hline 9 & Think & & & & + & \\
\hline 10 & Wait & + & + & + & & \\
\hline 11 & Or & + & & & & \\
\hline 12 & Minus & & & & + & \\
\hline
\end{tabular}


End of Table 2

\begin{tabular}{l|l|c|c|c|c|c}
\hline \multicolumn{1}{|c|}{ Gesture } & \multicolumn{1}{|c|}{1} & 2 & 3 & 4 & 5 \\
\hline 13 & Well done & + & + & + & & + \\
\hline 14 & Vice versa & + & + & + & & + \\
\hline 15 & Not satisfied & & + & & & \\
\hline 16 & No / you are wrong & + & + & & + & \\
\hline 17 & Open the manuals / copybooks & + & + & + & + & + \\
\hline 18 & Turn over the page & + & + & + & & \\
\hline 19 & Write down & + & + & + & + & + \\
\hline 20 & Repeat & & & + & & + \\
\hline 21 & Plus & & & & + & \\
\hline 22 & Work in pairs/groups & + & + & & & \\
\hline 23 & Open parenthesis & + & & + & & + \\
\hline 24 & Listen & + & + & + & + & \\
\hline 25 & Connect & + & + & & + & + \\
\hline 26 & Ask & + & + & + & + \\
\hline 27 & Be quiet & + & + & + & + \\
\hline 28 & Also & Read & I & + & + & + \\
\hline
\end{tabular}

Grammar categories

\begin{tabular}{c|l|c|c|c|c|c}
\hline 1 & Future tense & + & + & + & + & + \\
\hline 2 & Singular & + & + & + & + & + \\
\hline 3 & Separation by syllables & + & & + & & + \\
\hline 4 & Intonation & & + & + & & + \\
\hline 5 & Plural & + & + & & + & \\
\hline 6 & Present tense & + & + & + & + & + \\
\hline 7 & Word ending & & & & + & + \\
\hline 8 & Past tense & & + & + & + & + \\
\hline 9 & Suffix & & & & + & \\
\hline 10 & Stress mark & + & + & + & + & + \\
\hline
\end{tabular}




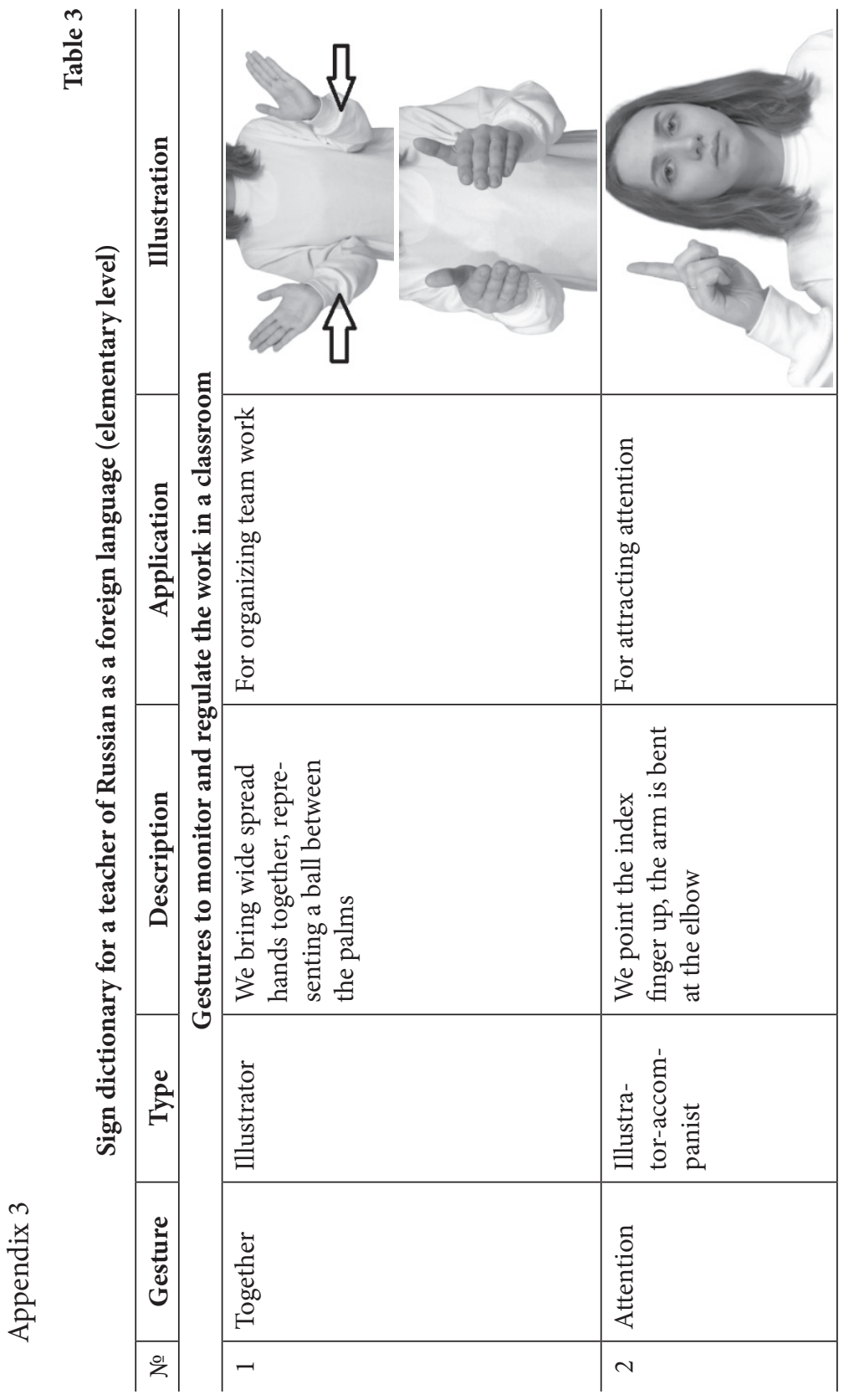




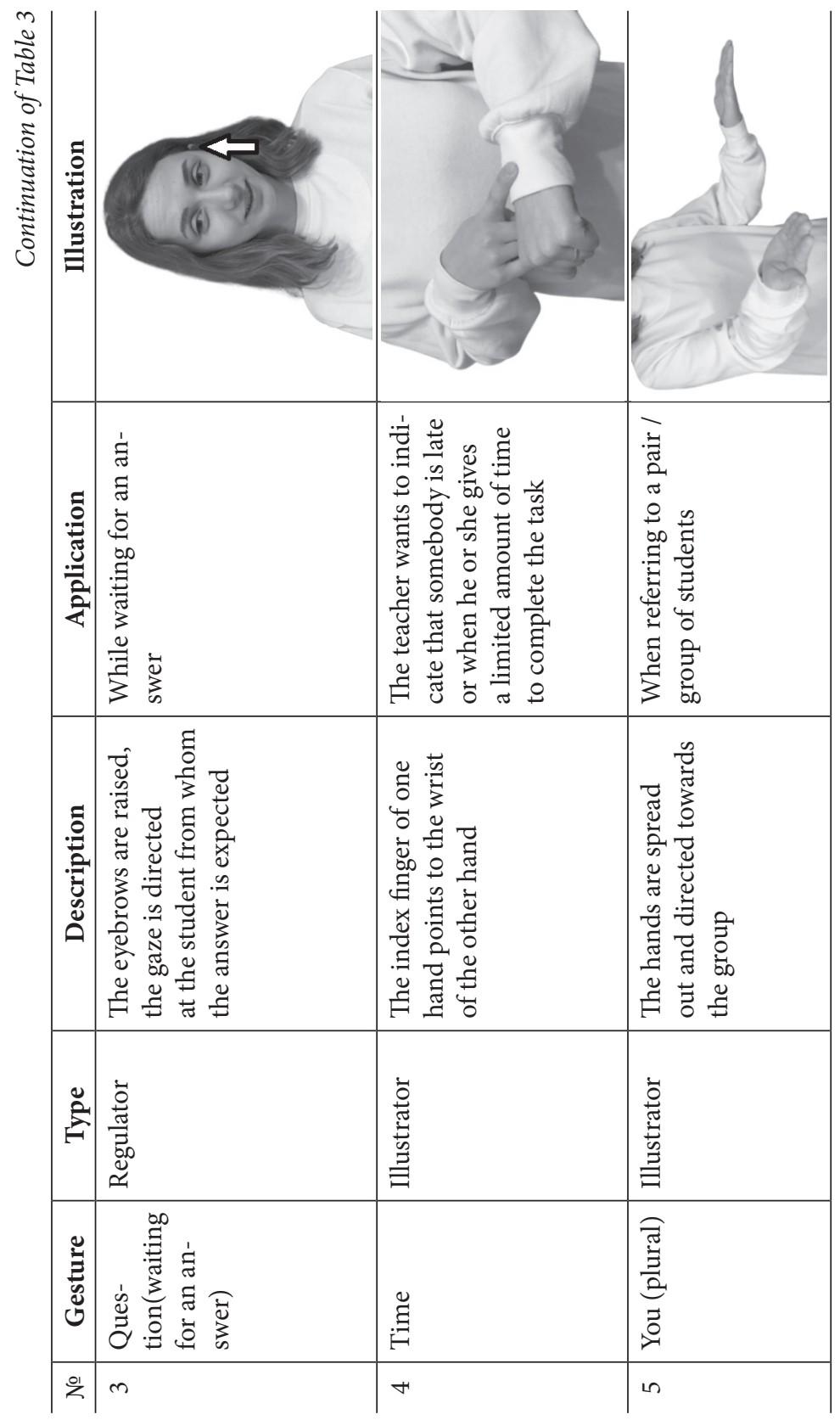




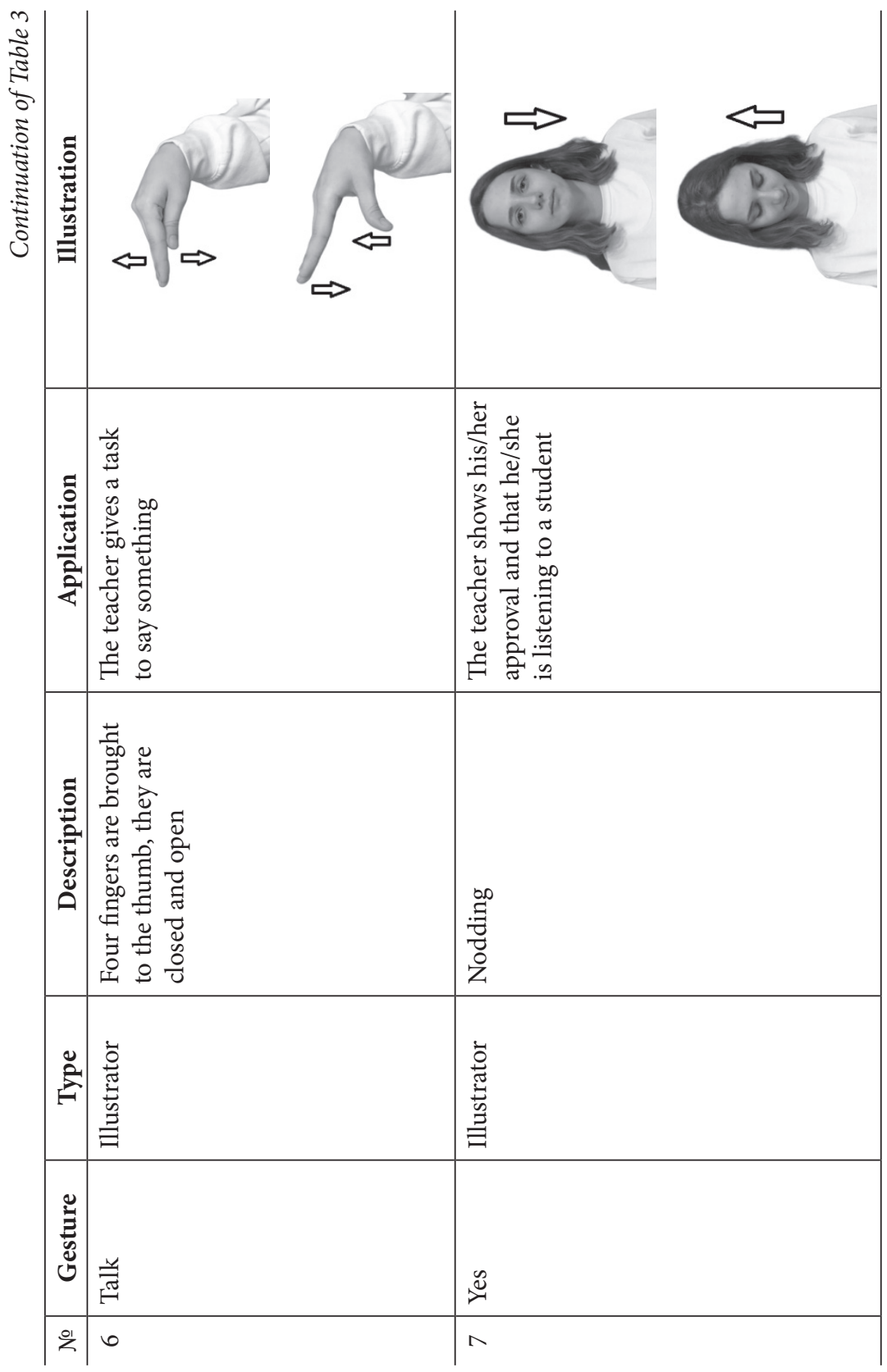




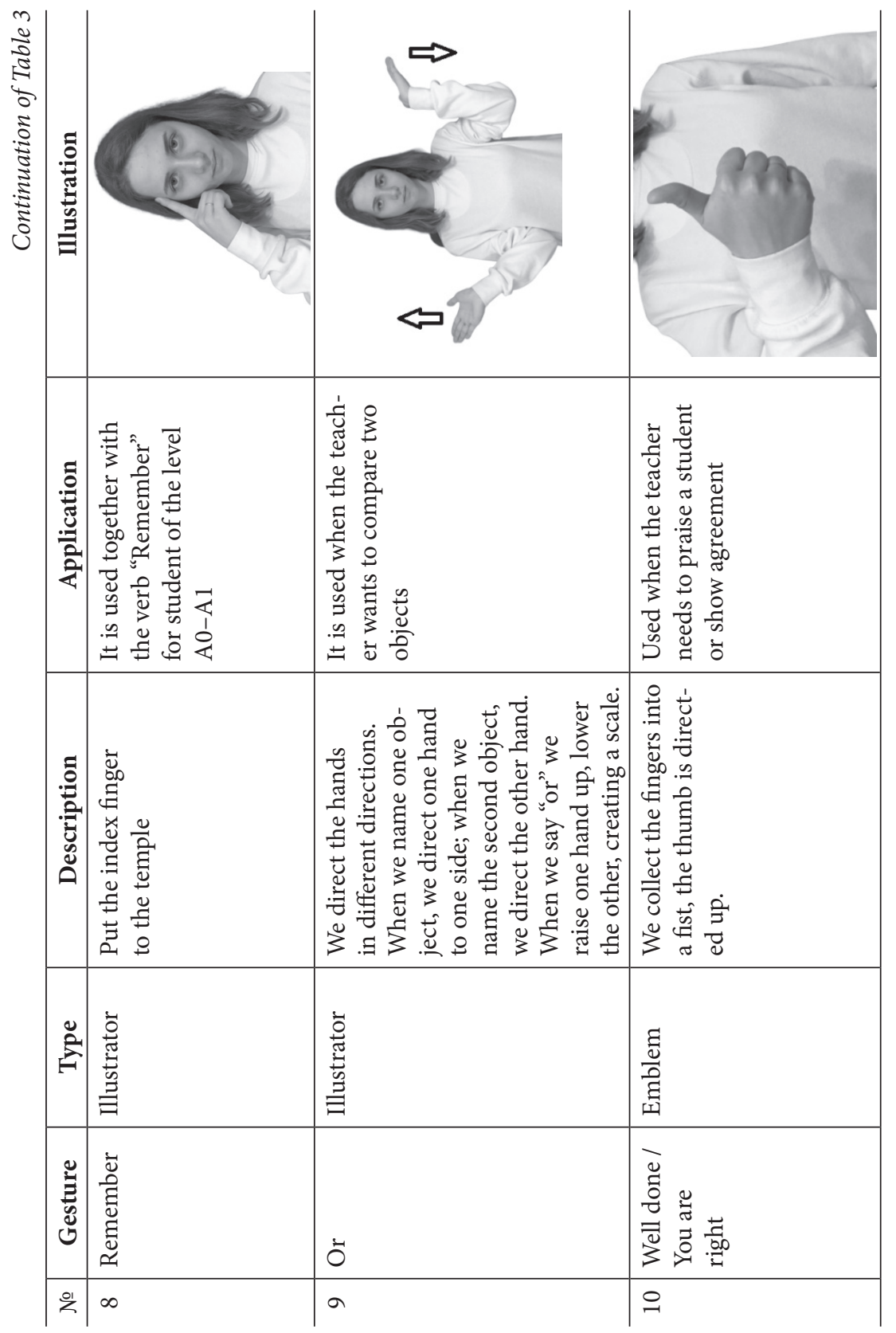


0
0
0
0
0
0
0
0
0
0
0
0
0
0
0

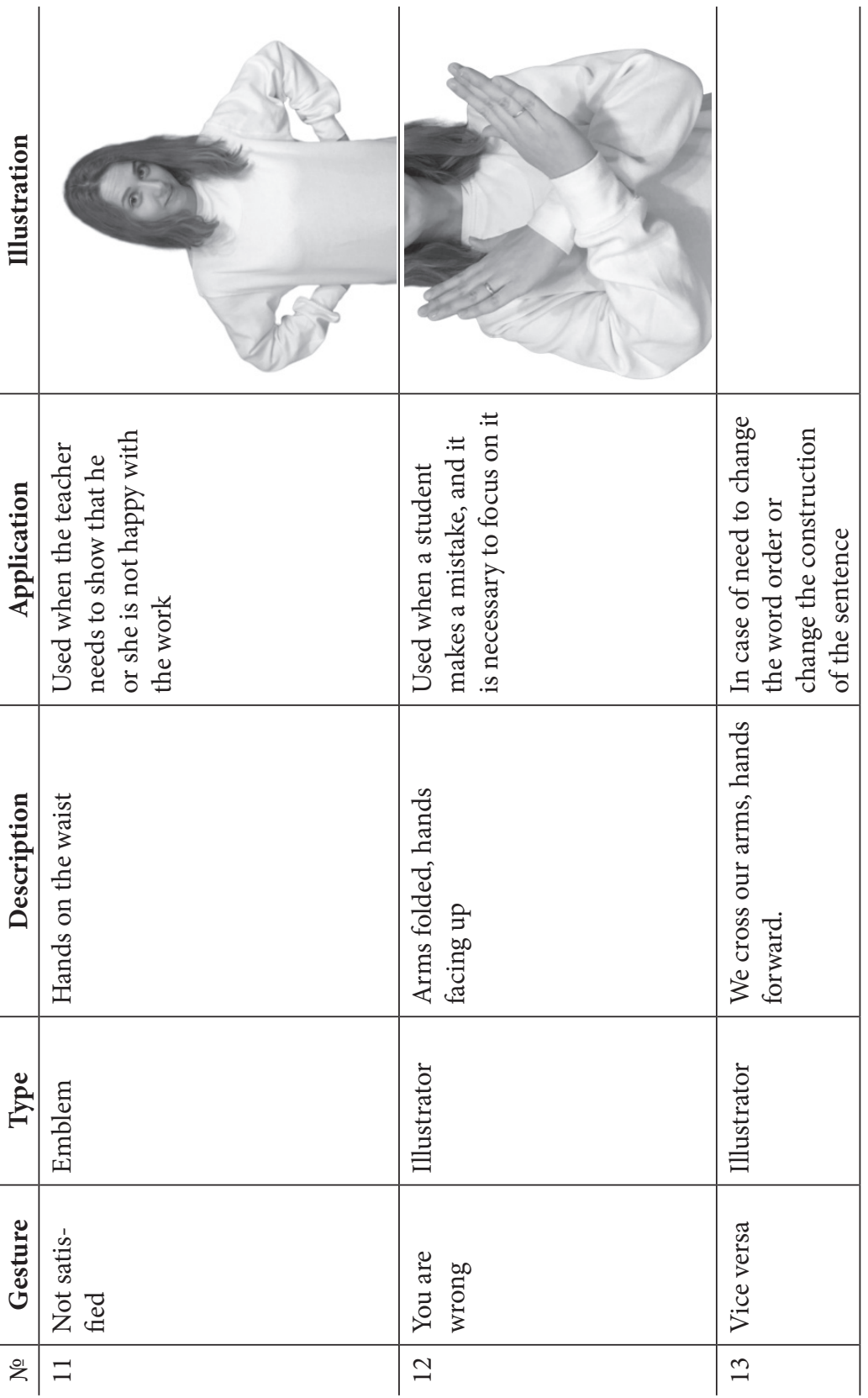




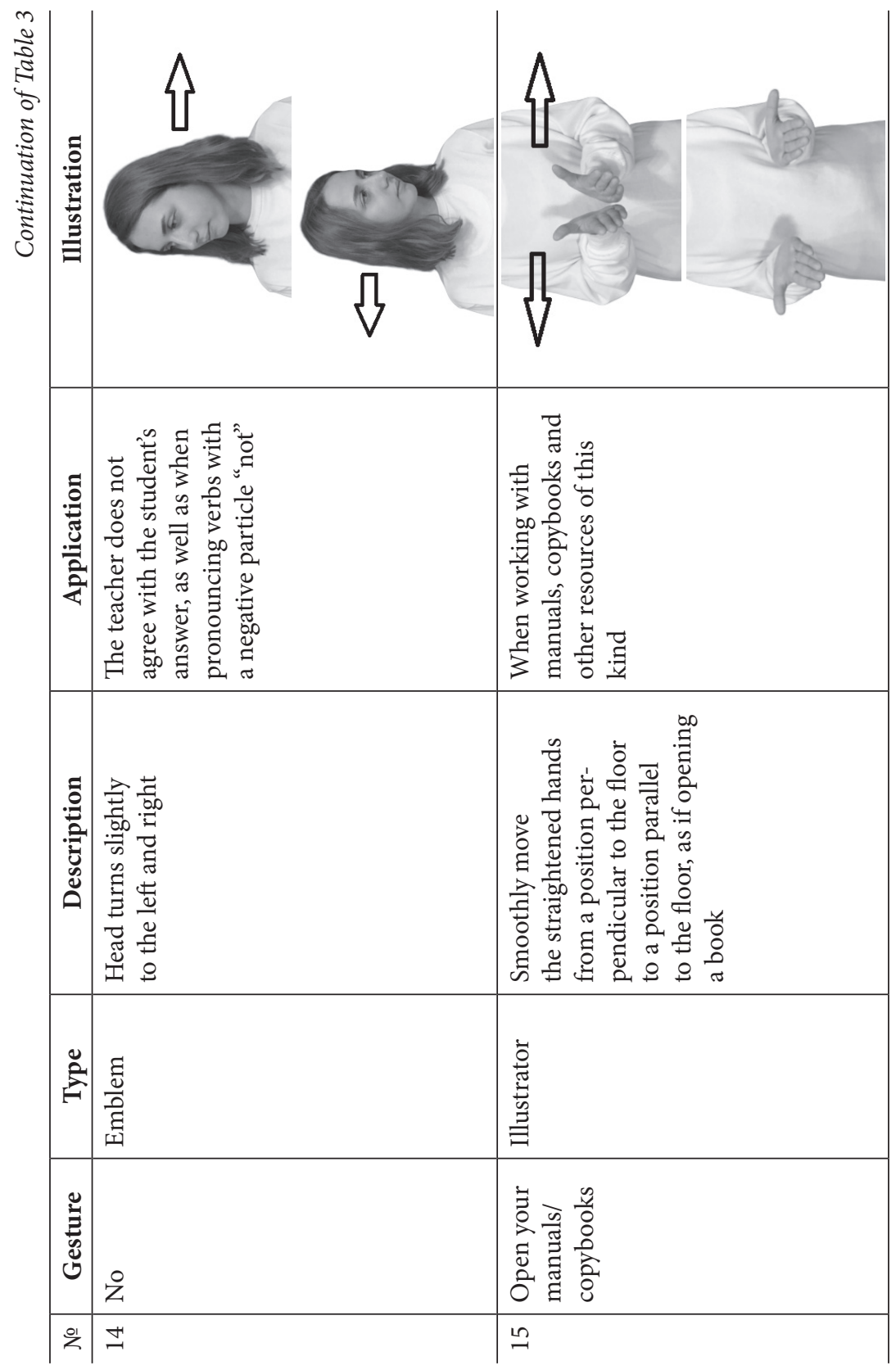




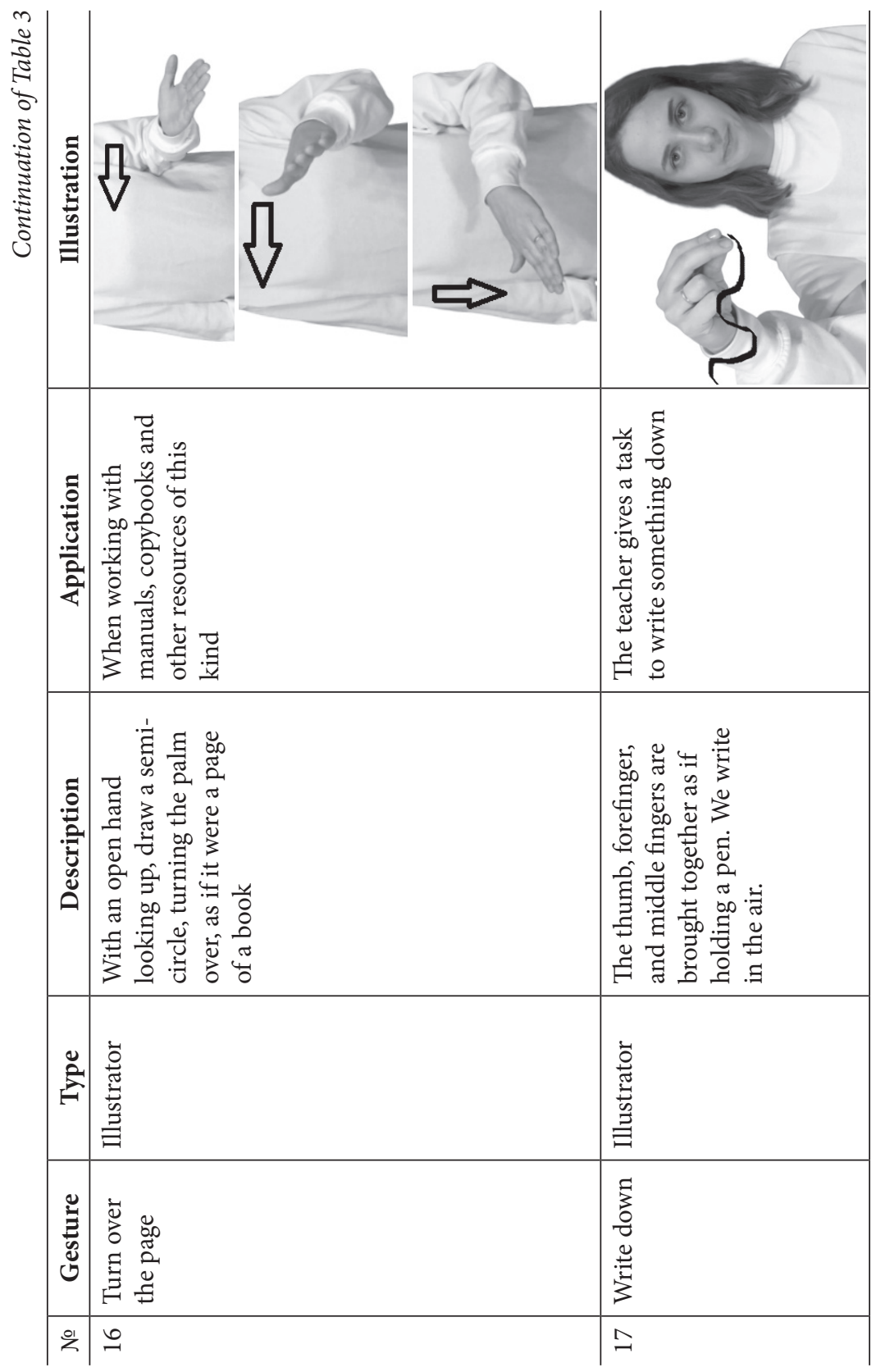




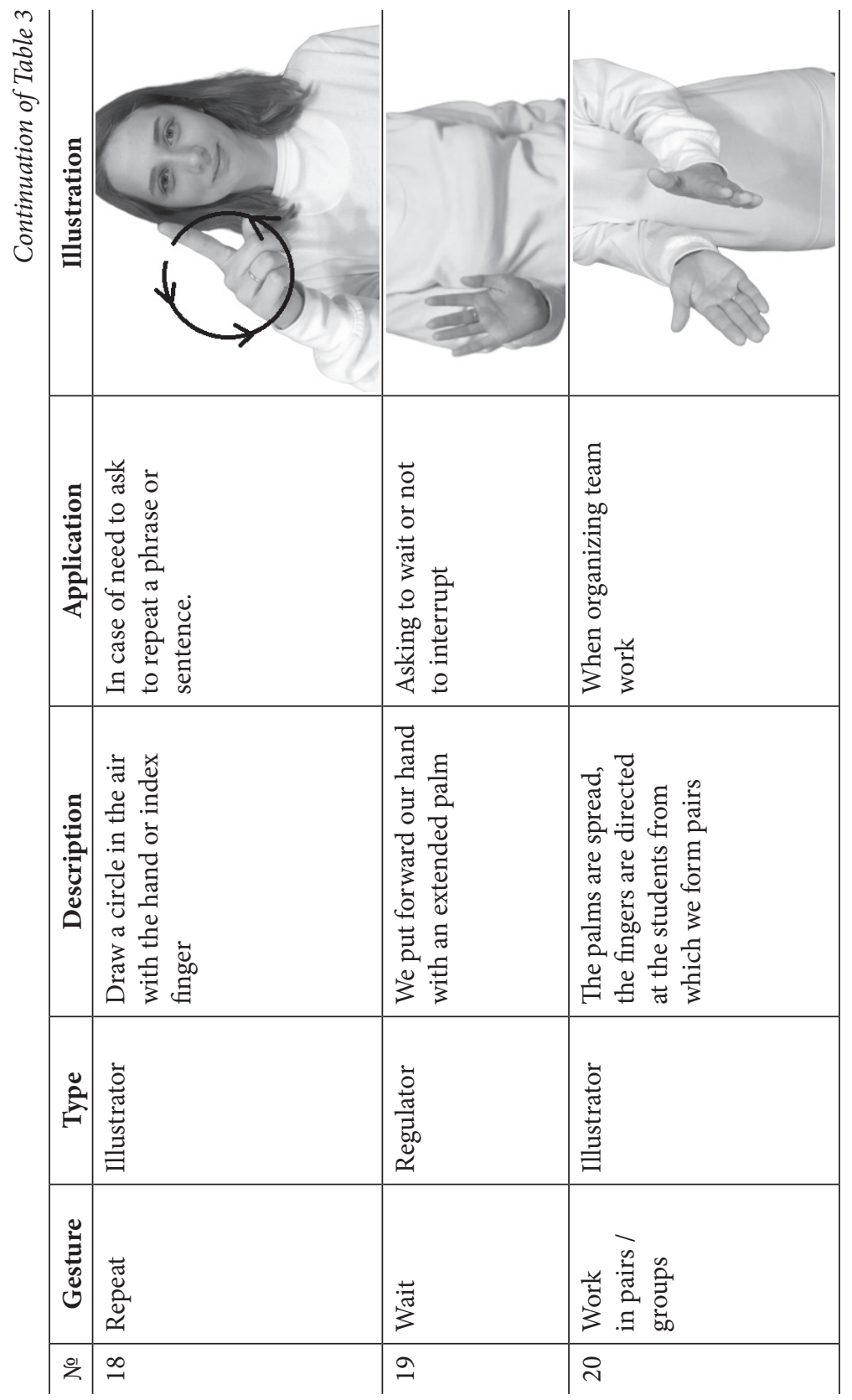


0
0
0
0
0
0
0
0
0
0
0
0
0
0
0
0
0

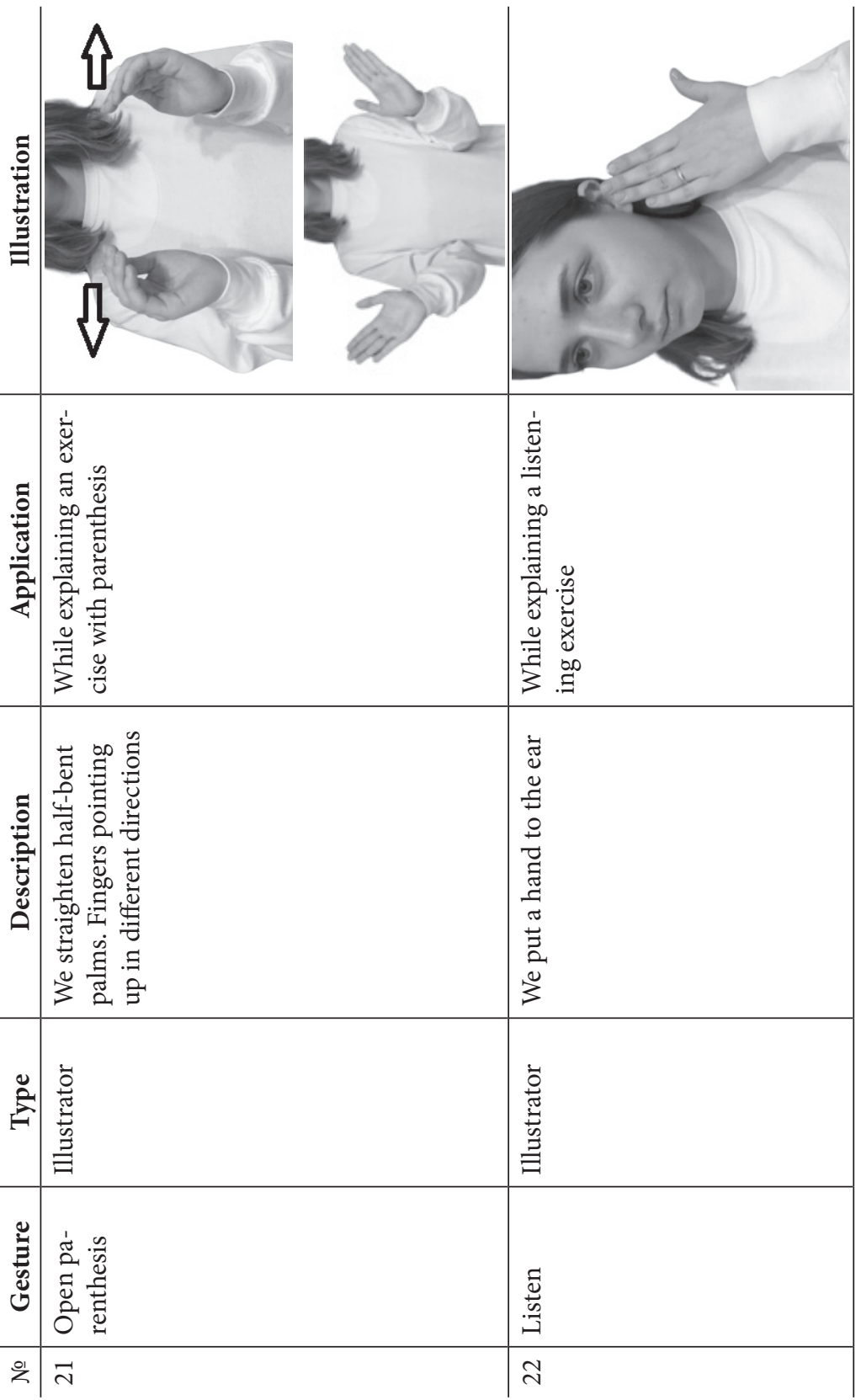




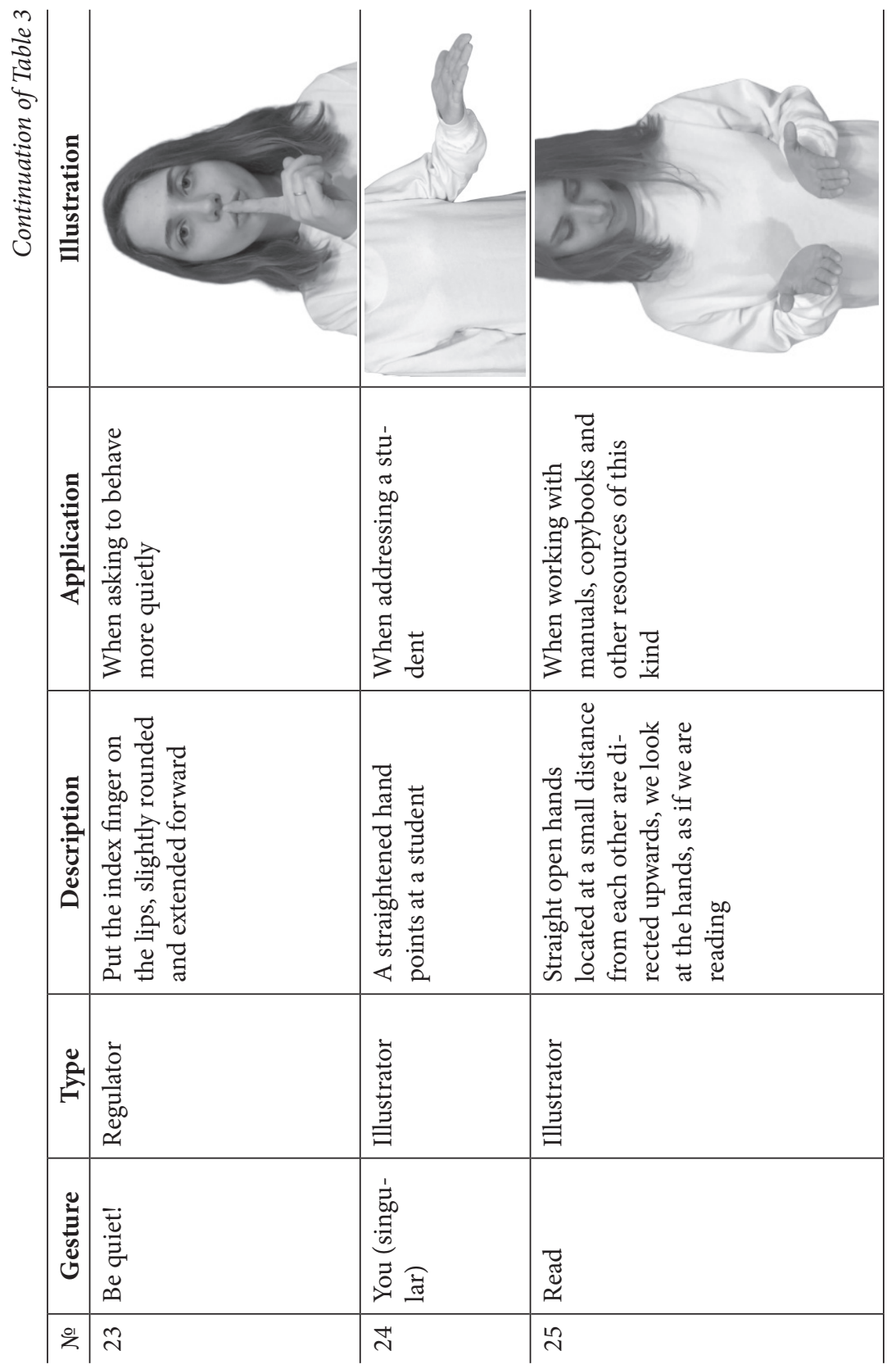




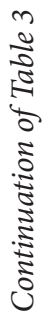

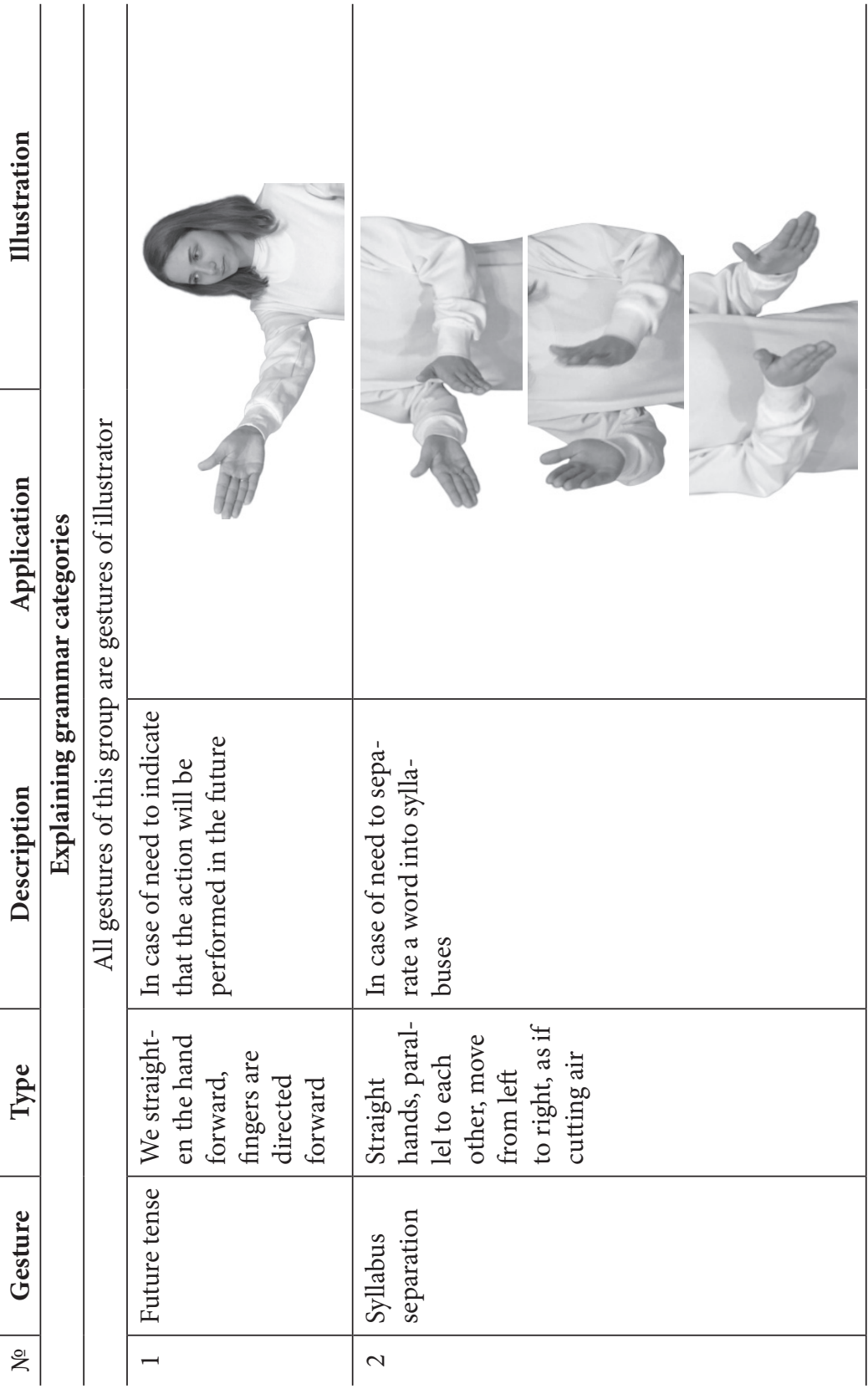




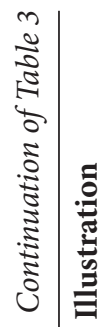

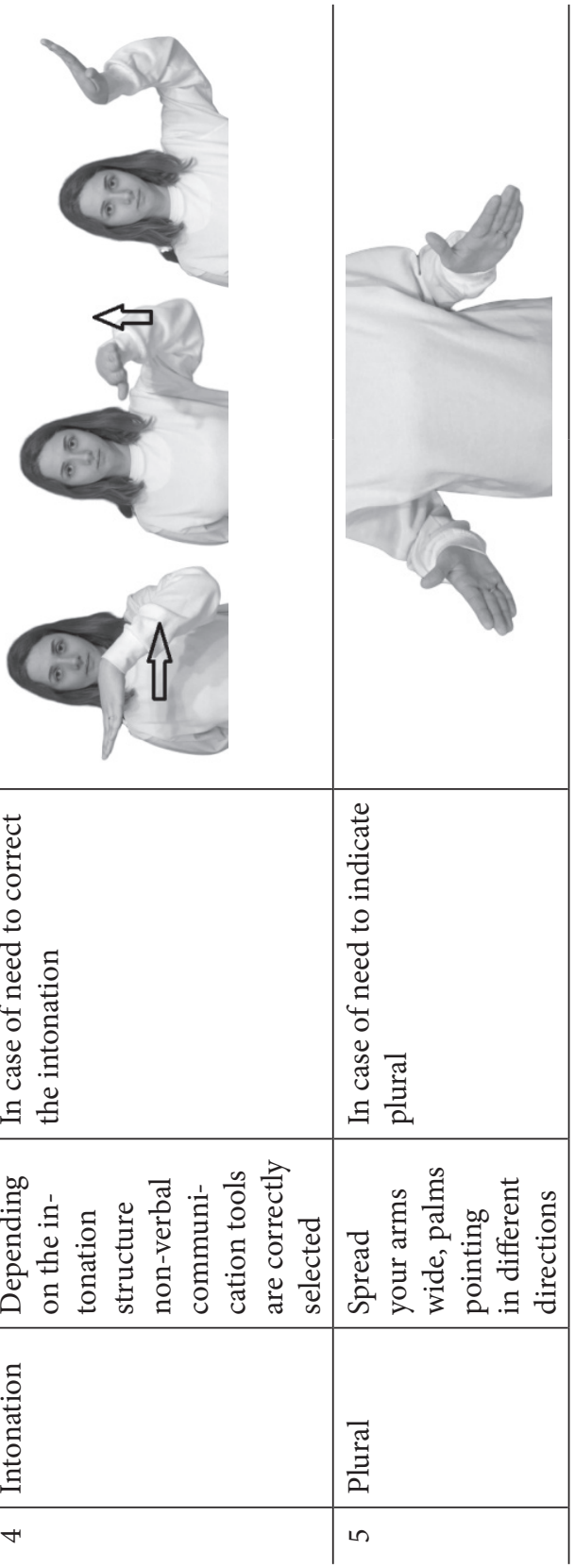




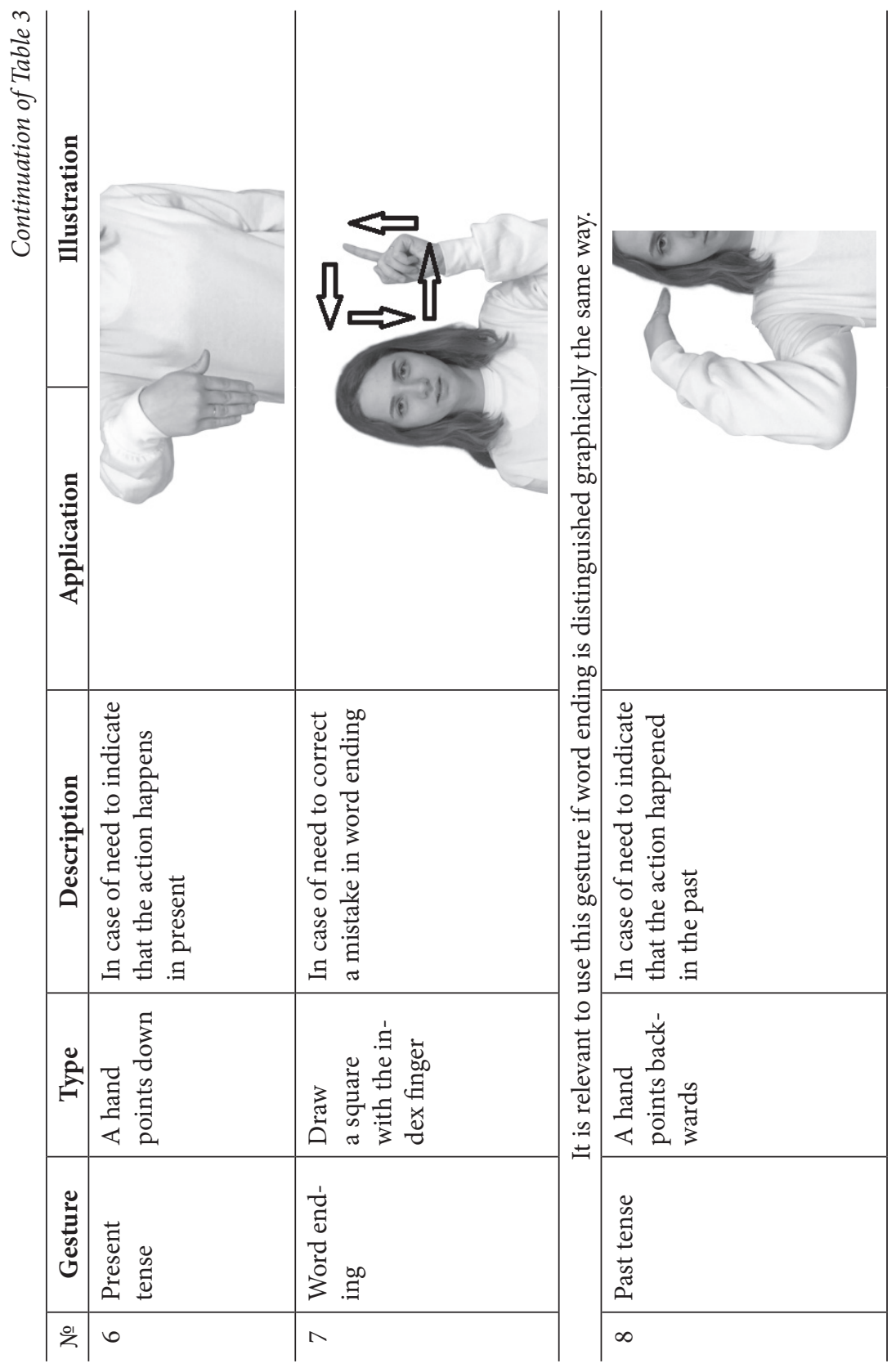


$\frac{2}{\frac{0}{0}}$

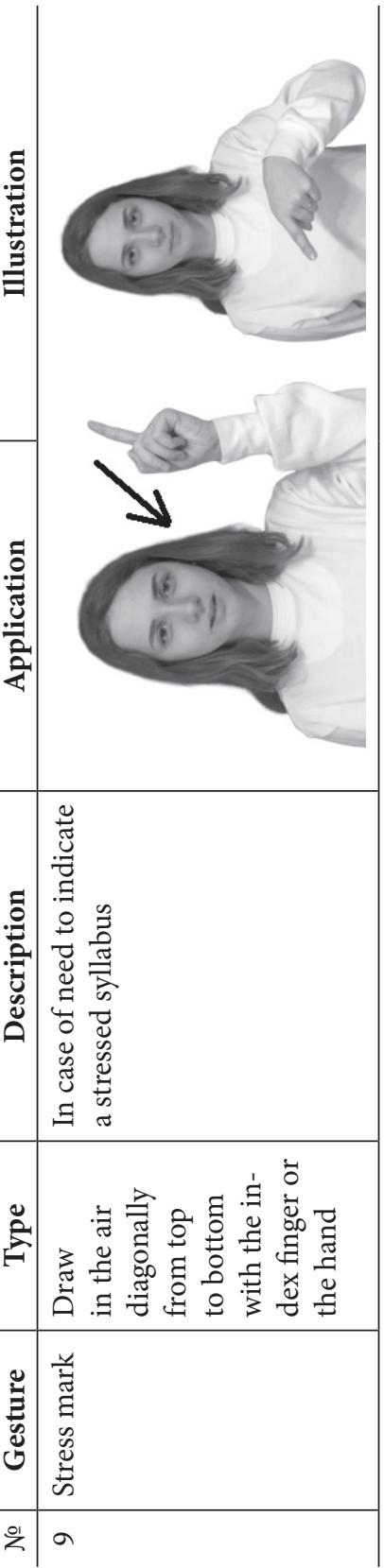




\section{Funding:}

This research was financially supported by the Russian Foundation for Basic Research № 18-012-00810 “Karelskoye Pomorye: dialectal lexis and onomastics (16th -21 st cc.)“.

\section{Conflict of Interest}

The authors have no conflict of interest to declare.

\section{References:}

1. O. V. Eremeeva. Protsess obucheniya inostrannomu yazyku: printsipy otbora neverbal'nykh sredstv kommunikatsii [The process of teaching a foreign language: the principles of selection of non-verbal means of communication]. Munitsipal'noye obrazovaniye: innovatsii i eksperiment, No. 2 (2015), pp. 53-56.

2. E. V. Talybina, E. V. Polyakova, N. A. Minakova. Neverbal'naya sostavlyayushchaya mezhkul'turnoy kommunikatsii pri obuchenii inofonov [Non-verbal component of intercultural communication in teaching foreigners] Vestnik Rossiyskogo universiteta druzhby narodov. Seriya: Russkiy i inostrannyye yazyki i metodika ikh prepodavaniya [Bulletin of the Peoples' Friendship University of Russia. Series: Russian and foreign languages and methods of teaching them], No. 1 (2015), pp. 16-20.

3. G.S. Nizamutdinova. Elektronnyye sredstva obucheniya v protsesse prepodavaniya russkogo yazyka kak inostrannogo: metod prezentatsii pri obuchenii neverbal'noy kommunikatsii [Electronic teaching tools in the process of teaching Russian as a foreign language: presentation method for teaching non-verbal communication]. Pedagogicheskoye obrazovaniye v Rossii [Pedagogical education in Russia], No. 11 (2016), pp. 71-77.

4. N.N. Volskaya. Kommunikativnyye sredstva neverbal'nogo povedeniya v aspekte prepodavaniya RKI [Communicative means of non-verbal behavior in the aspect of teaching RFL]. Kommunikativnyye issledovaniya [Communicative research], No. 3 (2017), pp. 134-141. DOI: 10.25513 / 2413-6182.2017.3.134-141.

5. Xiang Guangyun. Sposoby obucheniya mezhkul'turnoy neverbal'noy kommunikatsii studentov, izuchayushchikh russkiy yazyk kak inostrannyy [Methods of teaching intercultural non-verbal communication for students studying Russian as a foreign language]. Filologicheskiye nauki. Voprosy teorii i praktiki [Philological Sciences. Questions of theory and practice]. Diploma, Tambov, No. 7, Part 2 (2017), pp. 207-209.

6. O.A. Bejenari, N. V. Pomortseva. Russian and Italian non-verbal communication during lessons of Russian language as a foreign language: methodological aspect. 
Cross-Cultural Studies: Education and Science. Vol. 3, Issue I (2018), pp. 125-134 DOI: $10.24411 / 2470-1262-2018-10025$

7. O.N. Velikanova. Obucheniye kommunikativnomu povedeniyu na urokakh inostrannogo yazyka: neverbal'nyy aspekt [Teaching communicative behavior in foreign language lessons: the non-verbal aspect]. Izvestiya Volgogradskogo gosudarstvennogo pedagogicheskogo universiteta [Bulletin of the Volgograd State Pedagogical University]. No. 3 (2019), pp. 76-79.

8. E. V. Talybina, E. V. Polyakova, N. A. Minakova. Neverbal'naya sostavlyayushchaya mezhkul'turnoy kommunikatsii pri obuchenii inofonov [Non-verbal component of intercultural communication in teaching foreigners]. Neverbal'naya sostavlyayushchaya mezhkul'turnoy kommunikatsii pri obuchenii inofonov [Bulletin of the Peoples' Friendship University of Russia. Series: Russian and foreign languages and methods of teaching them] No. 1 (2015), pp. 16-20.

9. Rossiya v tsifrakh 2019 [Russia in numbers 2019] Federal. sluzhba gos. statistiki (Rosstat) [Federal state service statistics (Rosstat)]. ed. P. V. Malkova, Moscow (2019).

10. A. A. Yevtyugina. Sotsiokul'turnaya znachimost' festivalya v mezhkul'turnoy kommunikatsii i sotsializatsii inostrannykh studentov v vuze [Socio-cultural significance of the festival in intercultural communication and socialization of foreign students at the university]. Cross Cultural Studies: Education and Science. Vol. 3, Issue III, September (2018), pp. 453-458.

11. N. G. Urvantseva. Obrazovatel'naya sreda vuza v sotsiokul'turnoy adaptatsii inostrannykh studentov [The educational environment of the university in the socio-cultural adaptation of foreign students]. Pedagogika. Voprosy teorii i praktiki [Pedagogy. Questions of theory and practice]. Diploma, Tambov. Vol. 4, Issue. 3 (2019), pp. 59-63, https://doi.org/10.30853/pedagogy.2019.3.11

12. Y.V. Boldyrev. Vvedeniye v teoriyu mezhkul'turnoy kommunikatsii: kurs lektsiy. [Introduction to the theory of intercultural communication: a course of lectures]. Rus. yaz. Kursy, Moscow (2010).

13. N. N. Vasilyeva. Mezhkul'turnaya kompetentsiya. Strategii i tekhniki yeye dostizheniya [Intercultural competence. Strategies and techniques for achieving it] http://rspu.edu.ru/journals/lexicography/conference/vasilieva\%20N.htm/ (Accessed 15 August 2020).

14. I. L. Nabok. Pedagogika mezhnatsional'nogo obshcheniya: ucheb. posobiye dlya stud. vyssh. ucheb. zavedeniy [Pedagogy of interethnic communication: textbook. manual for stud. higher. study. institutions]. Academy, Moscow (2010).

15. A. Mehrabian. Nonverbal communication. New Brunswick, London (2009). 
16. N. N. Sergeeva, G. V. Pokhodzei. Razvitiye inoyazychnoy mezhkul'turnoy kompetentsii studentov neyazykovykh spetsial'nostey v sisteme professional'no-oriyentirovannogo yazykovogo obrazovaniya: monografiya [Development of foreign language intercultural competence of students of non-linguistic specialties in the system of professionally oriented language education: monography]. Ural. gos. ped. un-t. [Ural State Pedagogy University]. Ekaterinburg (2014).

17. M.L. Butovskaya. Yazyk tela: priroda i kul'tura (evolyutsionnyye i kross-kul'turnyye osnovy neverbal'noy kommunikatsii cheloveka). [Body language: nature and culture (evolutionary and cross-cultural fundamentals of human non-verbal communication)]. Nauchnyy mir, Moscow (2004).

18. L. V. Dubina. Issledovaniye neverbal'nykh sredstv kommunikatsii: monografiya [Research of non-verbal means of communication: monography]. Laboratoriya knigi, Moscow (2012).

19. V.Y. Antonova, M. M. Nakhabina, M. V. Safronova, A. A. Tolstykh. Doroga v Rossiyu [Road to Russia] Elementary level: textbook of the Russian language. 18th ed. Zlatoust, Saint Petersburg (2019).

20. S. I. Chernyshov. Poyekhali! [Let's go!] Russian for adults. Initial course. Zlatoust, Saint Petersburg (2016).

21. M.N. Anikina. Lestnitsa. Nachinayem izuchat' russkiy [Ladder. We start to learn Russian]. Textbook for foreign students of universities. 3rd ed., Stereotype. Rus. yazyk, Moscow (2007).

22. T.L. Esmantova. Russkiy yazyk: 5 elementov: uroven' A1 (elementarnyy) [Russian language: 5 elements: level A1 (elementary)]. Zlatous, Saint Petersburg (2018).

23. Y.G. Ovsienko. Russkiy yazyk dlya nachinayushchikh: ucheb. (dlya govoryashchikh na angliyskom yazyke) [Russian language for beginners: textbook. (for English speakers)]. Rus. yaz. Kursy, Moscow (2016).

24. M. M. Galeeva. Start-1. Vvodnyy i elementarnyy kursy: ucheb. rus. yaz. dlya podgot. fak. vuzov SSSR: kniga dlya studenta [Start-1. Introductory and elementary courses: textbook of the Russian language for preparation faculties of universities of the USSR: a book for the student]. 4th ed., Stereotype. Russkiy yazyk, Moscow (1986).

25. L. V. Miller, L. V. Politova, I. Y. Rybakova. Zhili-byli. 28 urokov russkogo yazyka dlya nachinayushchikh: ucheb. [Once upon a time. 28 Russian lessons for beginners: textbook]. Zlatoust, Saint Petersburg (2016). 